\title{
Interactive Effects between Cytokinin and Ethephon on Shoot Formation in Rhizome Cultures of Cymbidium kanran Makino
}

\author{
Kazuhiko SHIMASAKI \\ Department of Subtropical Agriculture, Kochi University, \\ Monobe B200, Nankoku-city, Kochi, 783 Japan
}

(Received November 3, 1993)

(Accepted September 17, 1994)

\begin{abstract}
Rhizomes of Cymbidium kanran were cultured in liquid Murashige and Skoog (MS) media supplemented with zeatin, BA and/or ethephon. Zeatin or BA induced shoot formation from rhizome cultures, but inhibited branching of rhizomes. Ethephon added to the culture medium alleviated the reduction of rhizome branching by cytokinins, but inhibited the cytokinin-induced shoot formation. Both zeatin and BA reduced the ethylene evolution from rhizome cultures. Zeatin reduced the ethephon-induced ethylene evolution, whereas, $0.01 \sim 1 \mu \mathrm{M}$ BA significantly enhanced the ethylene evolution by ethephon.
\end{abstract}

\section{Introduction}

Several investigators have previously reported cytokinin-induced shoot formation in rhizome cultures of Cymbidium kanran Makino and closely related species ${ }^{1-10}$.

Among these studies, we found that MS medium containing lower concentrations of nitrogen salts or the medium containing ethylene inhibitors, such as aminoethoxyvinylglycine(AVG) or silverthiosulfate (STS) promoted shoot formation of $C$. kanran rhizomes ${ }^{9,10)}$. Therefore, it was considered that the rhizome cultures producing lower levels of ethylene can develop shoots from the rhizome branches. In contrast, rhizome formation from shoot culture was enhanced in MS medium containing higher levels of auxin or ethylene, but was inhibited by $\mathrm{AVG}^{11}$.

This report describes the interactive effects between cytokinin and ethephon on shoot formation and ethylene evolution from rhizome cultures of C. kanran Makino.

\section{Materials and Methods}

Approximately $5 \mathrm{~mm}$ apical segments of $C$. kanran rhizome prepared by the methods described previously ${ }^{11)}$ were used as explants. Fifteen rhizome segments were cultured for each treatment. Liquid MS media containing $20 \mathrm{~g} / l$ sucrose and zeatin or benzylaminopurine (BA) at $0,0.01,0.1,1$. 0 and $10 \mu \mathrm{M}$ alone, or in combination with $10 \mu \mathrm{M}$ ethephon were used. Each medium was adjusted

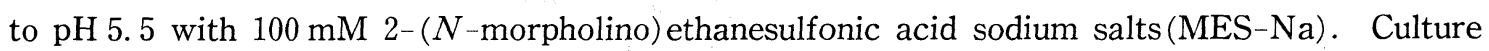
tubes $(25 \times 120 \mathrm{~mm})$ with plastic caps were used as culture vessels. Each contained $10 \mathrm{~m} l$ of liquid medium. The cultures were incubated for 8 weeks at $25 \pm 1^{\circ} \mathrm{C}$ without forced aeration under fluorescent light of $25 \mu \mathrm{E} / \mathrm{m}^{2} \mathrm{~s}$ for a 16 hour photoperiod.

For measuring the amount of ethylene, approximately $0.5 \mathrm{~g}$ of rhizome cultures were collected 
after 4 weeks of culture, rinsed 3 times with sterilized distilled water, and transferred into $20 \mathrm{~m} l$ syringe vials. One $\mathrm{m} l$ of gas sample was collected from each vial after incubating the rhizomes for 24 hours at $25 \pm 1^{\circ} \mathrm{C}$ under fluorescent light of $25 \mu \mathrm{E} / \mathrm{m}^{2} \mathrm{~s}$ for a 16 hour photoperiod, and the ethylene content was determined by gas chromatography (GC14A, Shimazu-Seisakusho, Kyoto) equipped with flame ionization detector. A stainless column, $100 \mathrm{~cm}$ long and $3 \mathrm{~mm}$ diameter, containing active alumina ( $70 \sim 80$ mesh) was used. The column temperature was kept at $100^{\circ} \mathrm{C}$. Rates of ethylene evolution were expressed on the fresh weight basis. At least 3 replications of rhizome cultures were measured for each treatment.

\section{Results}

Effects of zeatin and ethephon on rhizome growth and shoot formation are shown in Table 1. All of the rhizomes showed branching on MS media containing no phytohormone, whereas addition of zeatin in the culture medium inhibited the branching of rhizome. However, inhibiting effect of zeatin on rhizome branching was alleviated by ethephon and $100 \%$ of rhizome branching was obtained in the medium containing $0 \sim 0.1 \mu \mathrm{M}$ zeatin with $10 \mu \mathrm{M}$ ethephon. Rhizomes could produce rhizome branches in the phytohormone-free medium (Fig. 1-a), whereas a single application of zeatin at $0.01 \sim 1 \mu \mathrm{M}$ and the combination of ethephon with $10 \mu \mathrm{M}$ zeatin was effective for the induction of the rhizome-like shoots which differentiated leaves from a rhizome-like stem.
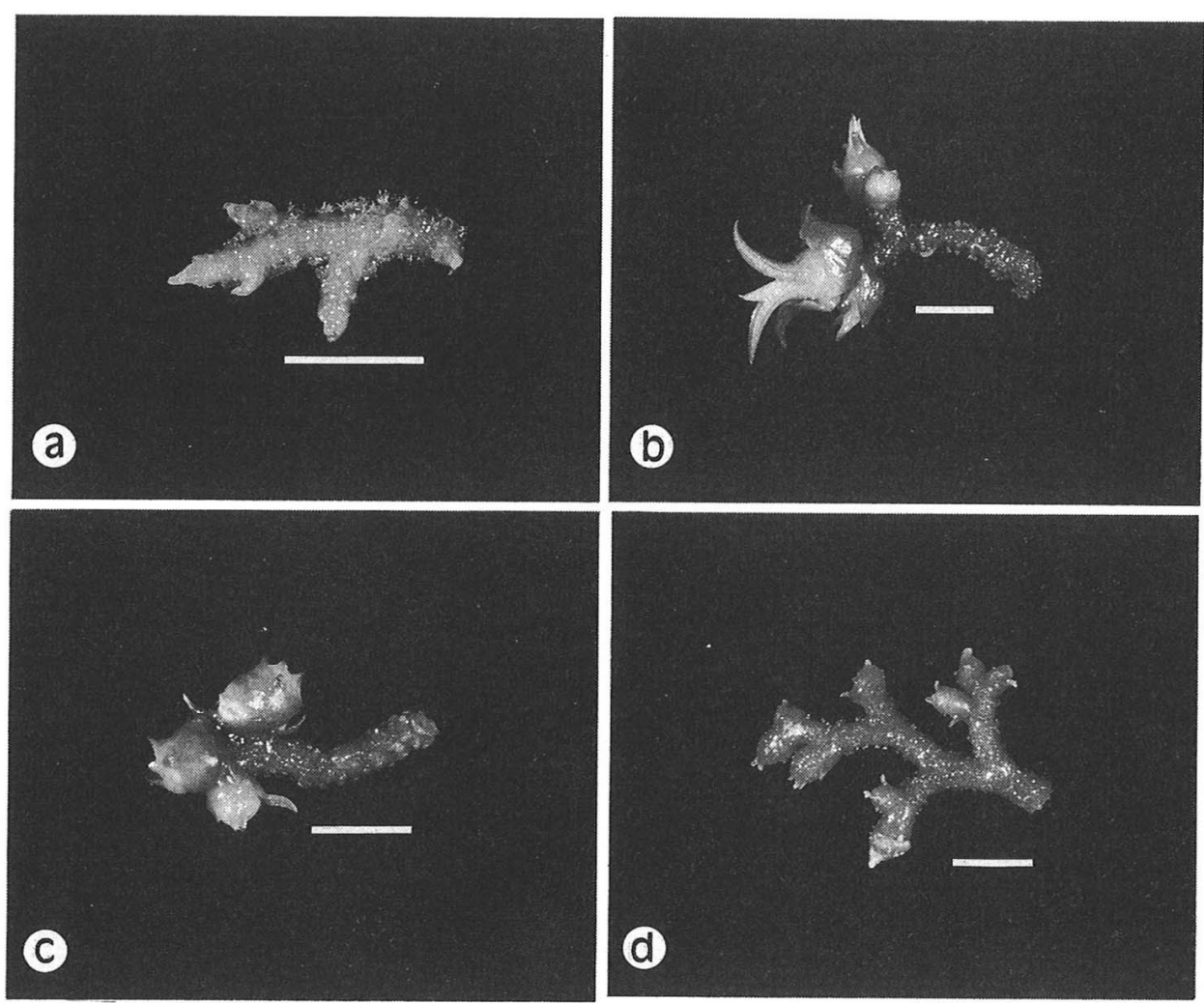

Fig. 1 Effects of cytokinins and ethephon added to liquid MS media on growth of rhizome cultures ( 8 weeks of culture). Bar $=5 \mathrm{~mm}$

(a) Rhizome cultured in hormone free medium.

(b) Protocorm-like shoot formation from a rhizome cultured with $10 \mu \mathrm{M}$ of zeatin.

(c) Protocorm-like shoot formation from a rhizome cultured with $10 \mu \mathrm{M}$ of $\mathrm{BA}$.

(d) Rhizome cultured in liquid MS medium supplemented with $0.1 \mu \mathrm{M} \mathrm{BA}$ and $10 \mu \mathrm{M}$ ethephon. 


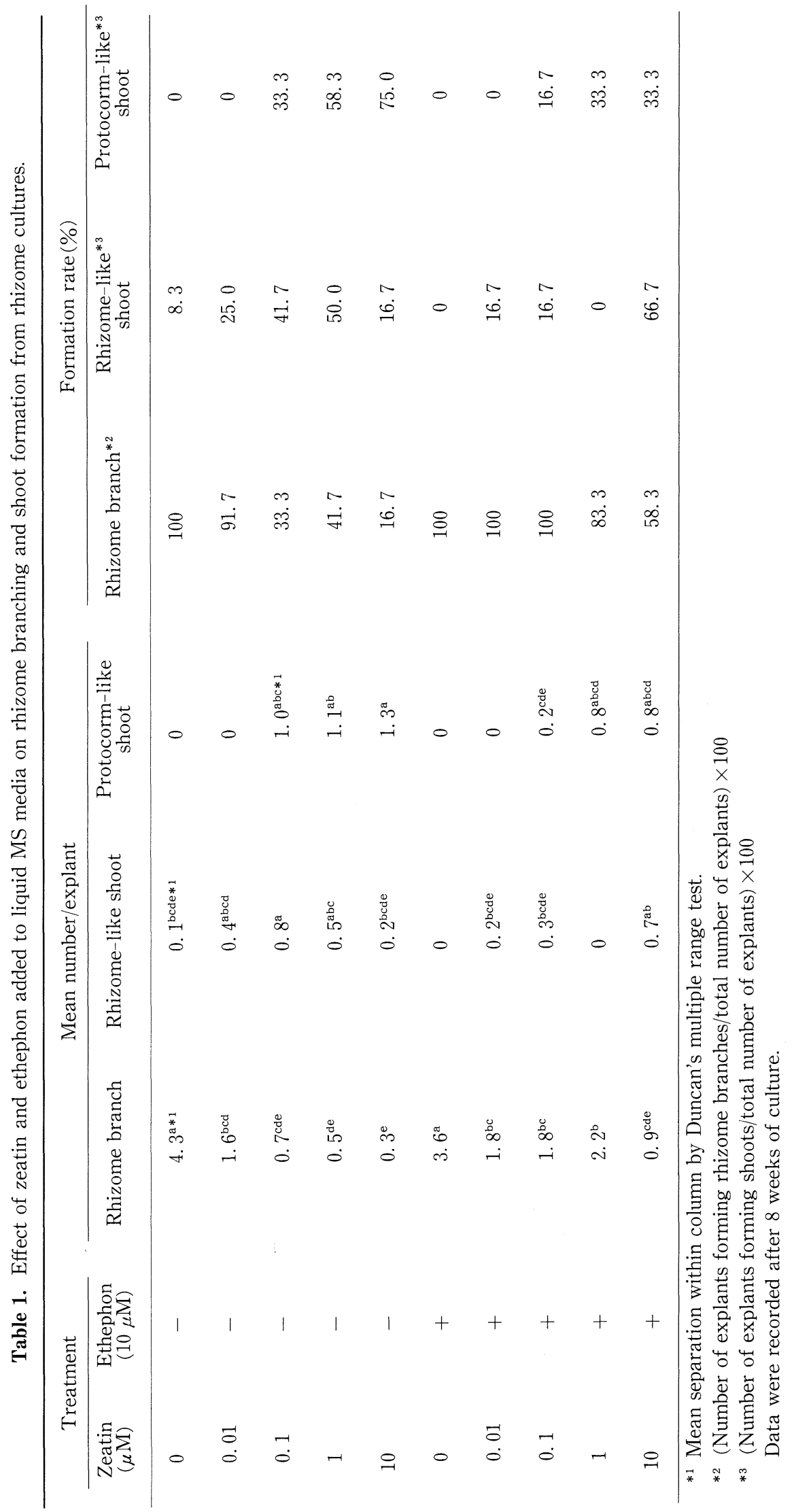




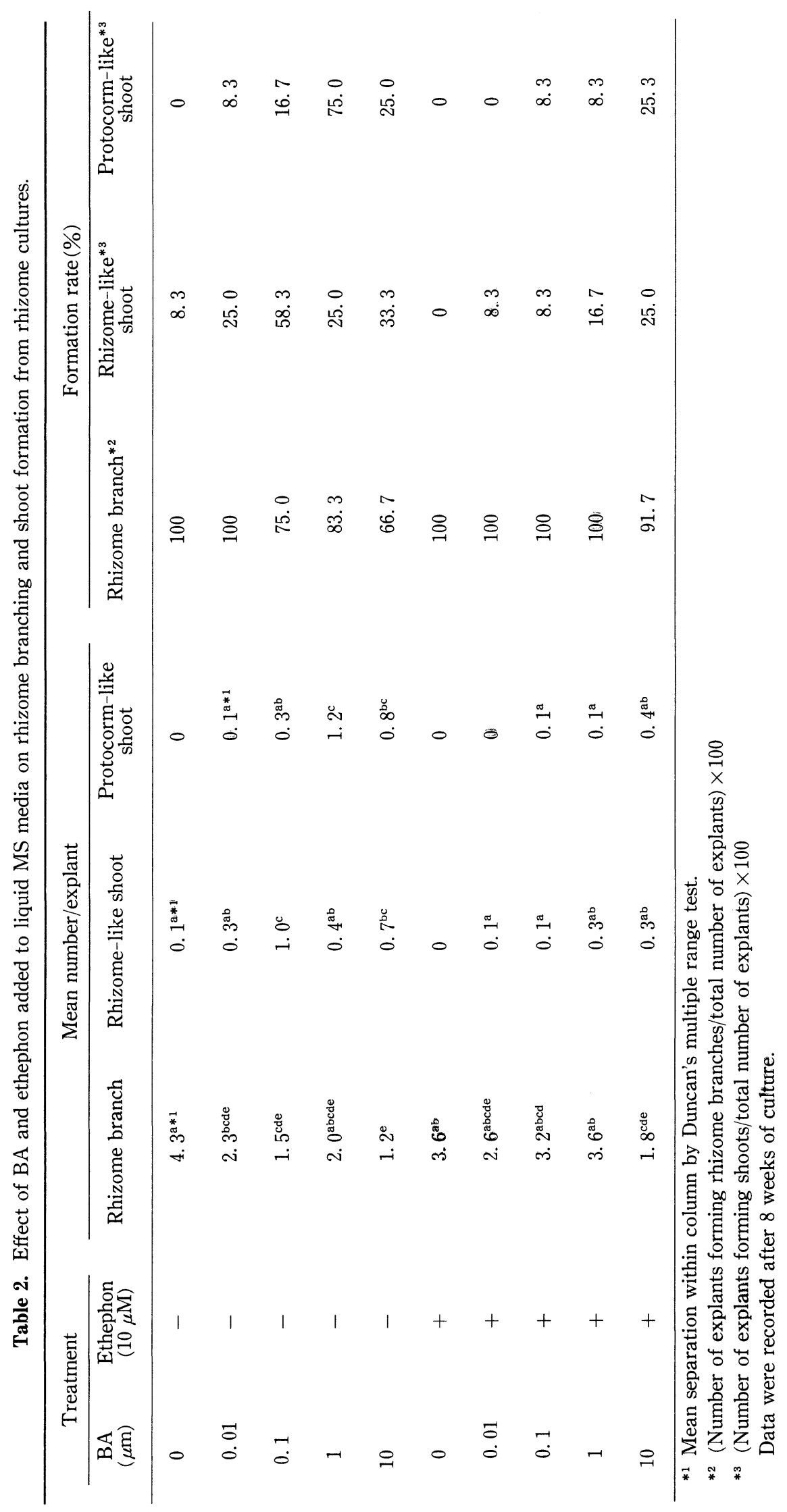


When $10 \mu \mathrm{M}$ ethephon was used alone or in combination with $0.01 \sim 1 \mu \mathrm{M}$ zeatin, it inhibited the formation of rhizome-like shoots. However, in the treatment of ethephon with $10 \mu \mathrm{M}$ zeatin, the highest rate $(66.7 \%$ ) of rhizome-like shoot formation was obtained. The addition of zeatin at concentrations of $0.1,1,10 \mu \mathrm{M}$, and the combination of ethephon with these high concentrations of zeatin resulted in the formation of protocorm-like shoots, and the maximum number and formation rate of the shoots were recorded for the treatment of $10 \mu \mathrm{M}$ zeatin. The inductive effect of the protocorm-like shoot(Fig. 1-b) by $0.1 \mu \mathrm{M}$ zeatin was completely removed by the addition of $10 \mu \mathrm{M}$ ethephon ot the culture medium.

BA had a similar effect to zeatin on rhizome growth and shoot formation(Table 2). The emergence of the rhizome branch was inhibited by application of BA. Simultaneous addition of 10 $\mu \mathrm{M}$ ethephon significantly removed the inhibitive effect of $0.01 \sim 1 \mu \mathrm{M}$ BA on rhizome branch formation. The formation rate of the rhizome branch was $100 \%$ at $0 \sim 0.01 \mu \mathrm{M} \mathrm{BA}$ alone and at three combinations of BA less than $1 \mu \mathrm{M}$ with ethephon.

The rhizome-like shoot formation was increased by the application of BA but reduced by ethephon. The addition of $\mathrm{BA}$ at concentrations of $0.01 \sim 10 \mu \mathrm{M}$ resulted in the formation of protocorm-like shoots $($ Fig. 1-c). The combination of ethephon with BA inhibited the differentiation of protocorm-like shoots from rhizome cultures (Fig. 1-d).

Fig. 2 shows the effect of zeatin and ethephon on ethylene production from C. kaniran rhizome cultures. Zeatin suppressed the ethylene evolution from rhizome cultures. This inhibitory effect

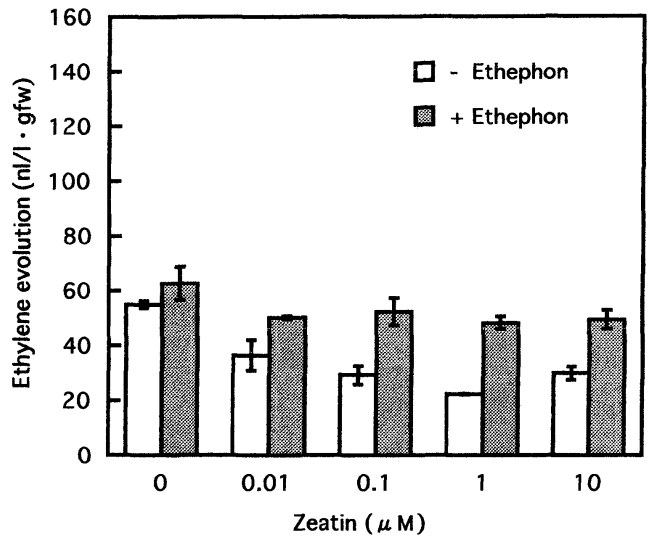

Fig. 2 Effect of zeatin and ethephon on ethylene evolution from rhizome cultures. Bars indicate $\mathrm{SE}(n=3)$

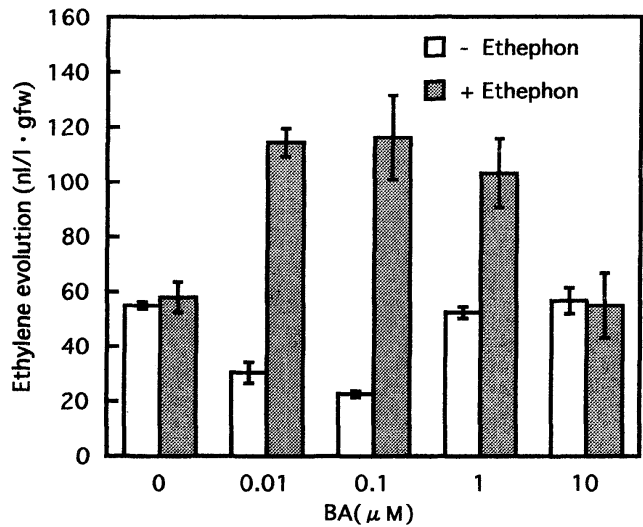

Fig. 3 Effect of BA and ethephon on ethylene evolution from rhizome cultures. Bars indicate $\mathrm{SE}(n=3)$ 
of zeatin on ethylene evolution was partially overcome by the application of ethephon.

The effect of BA on the ethylene production from rhizome cultures was slightly different from that of zeatin(Fig. 3). The ethylene production was inhibited by low concentrations $(0.01 \sim 0.1 \mu$ $\mathrm{M})$ of $\mathrm{BA}$, but no appreciable effect on ethylene evolution was observed at high concentrations (1 $\sim 10 \mu \mathrm{M})$. The application of $10 \mu \mathrm{M}$ ethephon with $0.01 \sim 1 \mu \mathrm{M}$ BA increased ethylene evolution twice of the control from rhizome cultures. However, the combination of ethephon with $10 \mu \mathrm{M}$ BA had no effect on the ethylene evolution.

\section{Discussion}

This study shows that both zeatin and BA in the culture medium reduce the branching of rhizomes and the addition of ethephon is able to alleviate the inhibition of rhizome branching by these cytokinins.

A single addition of zeatin or BA to the culture medium accelerated the shoot formation from rhizome cultures, although both cytokinins had little effect on longitudinal shoot elongation. The cytokinin-induced shoot formation was apparently inhibited by the ethephon treatment, which, however, promoted proliferation of rhizomes regardless of cytokinin in the culture medium. These results indicate that ethephon in the culture medium may play an important role in regulating cytokinin-induced shoot formation.

Evidently, cytokinin alone reduced the ethylene production from rhizome cultures. In previous reports using cut flowers of carnation ${ }^{12-15)}$, BA prevented the production and action of ethylene. In mung bean(Phaseolus mungo L.) hypocotyl segments, cytokinin had a synergistic effect with auxin on promoting auxin-induced ethylene production, because of the increase in auxin uptake $\mathrm{e}^{16}$. In the present study, zeatin slightly suppressed the ethephon-induced ethylene production in rhizome cultures, but BA at concentrations of $0.01 \sim 1.0 \mu \mathrm{M}$ significantly stimulated the ethephon-induced ethylene production. Therefore, it can be postulated that, BA at low concentrations promote the uptake of ethephon (ethylene) by rhizome cultures. The large increase of ethylene production by the combination of ethephon with BA may correspond with no significant reduction in the branching of rhizome at these BA concentrations. This result indicates that there is a synergistic effect between $\mathrm{BA}$ and ethephon with respect to ethylene evolution. Further experimentation is required to unravel the action mechanism of these phytohormones on the morphogenesis of rhizomes of $C$. kanran.

\section{References}

1) Ueda, H., H. Torikata, 1986. In "Seed formation and sterile culture of the orchids" (ed. by Torikata, H.). p. 271-283, Seibundo-Shinkosha, Tokyo.

2) Ueda, H., H. Torikata, 1986. J. Japan. Soc. Hort. Sci., 37: 240-248.

3) Hasegawa, A., H. Ohashi, M. Goi, 1985. Acta Hortic., 166: 25-40.

4) Hasegawa, A., M. Goi, 1987. J. Japan. Soc. Hort. Sci., 56: 70-78.

5) Kokubu, T., Y. Kaieda, Y. Higashi, T. Kitano, K. Fukamizu. 1980. Mem. Fac. Agric. Kagoshima Univ., 16: 53-64.

6) Lee, Js., Is. So, 1985. Subtrop. Agric. Cheju Nat. Univ., 5: 49-59.

7) Lee, Js., Is. So, 1985. Cheju Nat. Univ. J., 27: 21-27.

8) Lee, Js., 1988. Subtrop. Agric. Cheju Nat. Univ., 5: 49-59.

9) Shimasaki, K., S. Uemoto, 1990. Plant Cell Tissue and Organ Culture, 22: 237-244.

10) Shimasaki, K., 1992. Plant Tissue Culture Letters, 9: 202-205. 
11) Shimasaki, K., 1993. Plant Tissue Culture Letters, 10: 156-159.

12) Eisinger, W., 1977. Plant Physiol., 59: 707-709.

13) Eisinger, W., 1982. Plant Physiol., 69: S136(Abstr.).

14) Mor, Y., H. Spiegelstein, A. H. Halevy, 1983. Plant Physiol., 71: 541-546.

15) Cook. G., M. Rashe, W. Eisinger, 1985. J. Amer. Soc. Hort. Sci., 110: 24-27.

16) Lau, O, S. F. Young, 1973. Plant Physiol., 51: 1011-1014.

\section{《和文要約》}

カンラン(Cymbidium kanran Makino)のライゾームからの

シュート形成に及ぼすサイトカイニンとエテフォンの相互作用

島崎一彦

高知大学農学部

カンラン(Cymbidium kanran Makino)のライゾームをゼアチン，BA 及びエテフォンを添加した液体 MS 培地で培養した。 ゼアチン及び BA 単独添加区でシュート形成が認められたが, ライゾームの分枝は抑 制された。エテフォンはサイトカイニンによるライゾームの分枝抑制作用を軽隇したが，シュート形成を抑 制した。ゼアチン並びに BA 単独処理区ではともにライゾームからのエチレン放散が抑制された. エテフ オン処理によって誘導されるエチレン生成はゼアチン処理区で抑制されたが, $0.01 〜 1 \mu \mathrm{M} \mathrm{BA}$ 処理区では 著しく促進された. 